\title{
Southern Ocean Sector Centennial Climate Variability and Recent Decadal Trends
}

\author{
MOJIB LATIF \\ Helmholtz Centre for Ocean Research Kiel, and Kiel University, Kiel, Germany \\ TORGE MARTIN \\ Polar Science Center, Applied Physics Laboratory, University of Washington, Seattle, Washington \\ WONSUN PARK \\ Helmholtz Centre for Ocean Research Kiel, Kiel, Germany
}

(Manuscript received 17 May 2012, in final form 8 April 2013)

\begin{abstract}
Evidence is presented for the notion that some contribution to the recent decadal trends observed in the Southern Hemisphere, including the lack of a strong Southern Ocean surface warming, may have originated from longer-term internal centennial variability originating in the Southern Ocean. The existence of such centennial variability is supported by the instrumental sea surface temperatures (SSTs), a multimillennial reconstruction of Tasmanian summer temperatures from tree rings, and a millennial control integration of the Kiel Climate Model (KCM). The model variability was previously shown to be linked to changes in Weddell Sea deep convection. During phases of deep convection the surface Southern Ocean warms, the abyssal Southern Ocean cools, Antarctic sea ice extent retreats, and the low-level atmospheric circulation over the Southern Ocean weakens. After the halt of deep convection the surface Southern Ocean cools, the abyssal Southern Ocean warms, Antarctic sea ice expands, and the low-level atmospheric circulation over the Southern Ocean intensifies, consistent with what has been observed during the recent decades. A strong sensitivity of the time scale to model formulation is noted. In the $\mathrm{KCM}$, the centennial variability is associated with global-average surface air temperature (SAT) changes of the order of a few tenths of a degree per century. The model results thus suggest that internal centennial variability originating in the Southern Ocean should be considered in addition to other internal variability and external forcing when discussing the climate of the twentieth century and projecting that of the twenty-first century.
\end{abstract}

\section{Introduction}

The global-average surface air temperature (SAT) did strongly increase during the recent decades. Most of the surface warming occurred in the Northern Hemisphere, while the Southern Hemisphere warmed considerably less (Trenberth et al. 2007). The near-global-average sea surface temperature (SST) did increase by about $0.2^{\circ} \mathrm{C}$ during the last four decades, as estimated here by the difference of the bidecadal mean 1991-2010 relative to that of 1971-90 (Fig. 1). Strong regional variation, however,

Corresponding author address: Mojib Latif, Research Division Ocean Circulation and Climate Dynamics, GEOMAR Helmholtz Centre for Ocean Research Kiel, Düsternbrooker Weg 20, 24105 Kiel, Germany.

E-mail:mlatif@geomar.de is obvious in the SST trend pattern with remarkably little warming over most of the Southern Ocean (Fig. 1a). In contrast, the abyssal Southern Ocean considerably warmed during the recent decades (Robertson et al. 2002; Purkey and Johnson 2010, 2012; Fahrbach et al. 2011). Finally, while the Arctic sea ice extent strongly declined during the satellite era, the Antarctic sea ice extent increased (e.g., Cavalieri and Parkinson 2008; Comiso and Nishio 2008). In fact while the Arctic sea ice extent featured a record minimum during September 2012, the Antarctic sea ice extent reached a record high during the same month. These seemingly conflicting decadal trends often cause confusion in the public and raise questions about the validity of global warming.

Climate variability can be either generated internally by interactions within or between the individual climate system components (e.g., atmosphere, ocean, sea ice, 

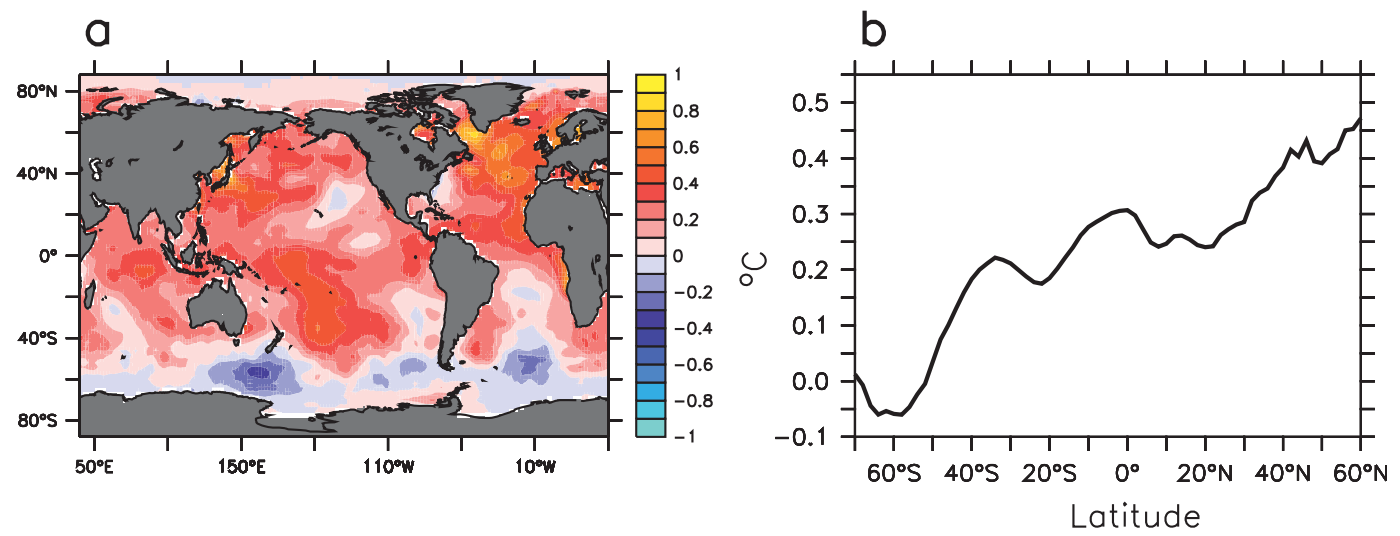

FIG. 1. SST anomalies $\left({ }^{\circ} \mathrm{C}\right)$ during the recent decades based on the extended reconstructed SST, version $3 \mathrm{~b}$ (ERSST. v3b; Smith et al. 2008; http://www.ncdc.noaa.gov/ersst/). (a) Global pattern of annual SSTs averaged over the period 1991-2010 presented as anomalies relative to the period 1971-90. (b) The corresponding zonal-mean temperature anomalies. While the Northern Hemisphere experienced a strong warming during the recent decades, the Southern Hemisphere warmed only little. The global-average SST difference between the two time periods amounts to $0.2^{\circ} \mathrm{C}$.

and land) or externally by, for example, volcanic eruptions, variations in the solar insolation at the top of the atmosphere, or changed atmospheric greenhouse gas and aerosol concentrations in response to anthropogenic emissions. Prominent examples of internal variability are the North Atlantic Oscillation (NAO; Hurrell 1995), originating from the chaotic atmospheric dynamics; the El Niño-Southern Oscillation (ENSO; Philander 1990), a coupled ocean-atmosphere mode on interannual time scales; the Pacific decadal oscillation (PDO; Mantua et al. 1997); the interdecadal Pacific oscillation (IPO; Power et al. 1999); or the Atlantic multidecadal oscillation (AMO; Knight et al. 2005). Some internal variations strongly project onto global, hemispheric, or regional SAT, thereby masking the effects of anthropogenic climate change. It is therefore of primary importance to understand the dynamics, predictability, and global impacts of internal variability on those time scales on which anthropogenic climate change evolves.

A prominent event in the Southern Ocean during the twentieth century was the Weddell Polynya (e.g., Zwally and Gloersen 1977; Carsey 1980; Gordon and Comiso 1988), a large area $\left(350000 \mathrm{~km}^{2}\right)$ of open water within the ice-covered Weddell Sea during the austral winters of 1974-76. There was vigorous air-sea interaction within the polynya that resulted in the convective overturning of the water column and the formation of vast amounts of cold and very dense Antarctic Bottom Water (Gordon 1978, 1982). Moreover, the Weddell Polynya had a profound impact on the surface meteorology of the region (Moore et al. 2002). Different assertions have been made about the origin of the Weddell Polynya (Martinson et al. 1981; Parkinson 1983; Holland 2001; Gordon et al. 2007), but its origin is still controversial.
During the instrumental period, the SST of the Southern Ocean exhibited a pronounced centennial variability as demonstrated by its zonal average in the latitude band $50^{\circ}-70^{\circ} \mathrm{S}$, which will be referred to as the Southern Ocean centennial variability (SOCV) index (Fig. 2a). The Weddell Polynya obviously coincided with the last warm phase of the SOCV index. Since then, the SOCV index declined and Antarctic sea ice extent expanded. Is it possible that the Weddell Polynya and the subsequent evolution of Antarctic sea ice can be understood in terms of longer-term centennial variability in the Southern Ocean?

The sea level pressure (SLP) gradient across the Southern Ocean intensified during the recent decades, as expressed by the positive trend in the southern annular mode (SAM) index (Thompson and Solomon 2002; Marshall 2003; Visbeck 2009). The SAM is the most energetic atmospheric circulation pattern of the Southern Hemisphere, and its enhancement was associated with stronger-than-normal surface westerly winds over the Southern Ocean (Visbeck 2009). Thompson et al. (2011) argue that surface climate change as far equatorward as the subtropical Southern Hemisphere may have been affected by the Antarctic ozone hole. Marshall et al. (2004), on the basis of a climate model, postulate that the recent observed trend in the SAM index is unlikely to be due to internal climate variability, but they assign a stronger role to natural external forcing than Thompson et al. (2011). We emphasize here the potential role of internal SOCV in forcing the SAM.

A lot of research during the last years was devoted to the Northern Hemisphere decadal-to-multidecadal variability. Latif and Keenlyside (2011) provide a review of decadal variability and predictability. Many papers 

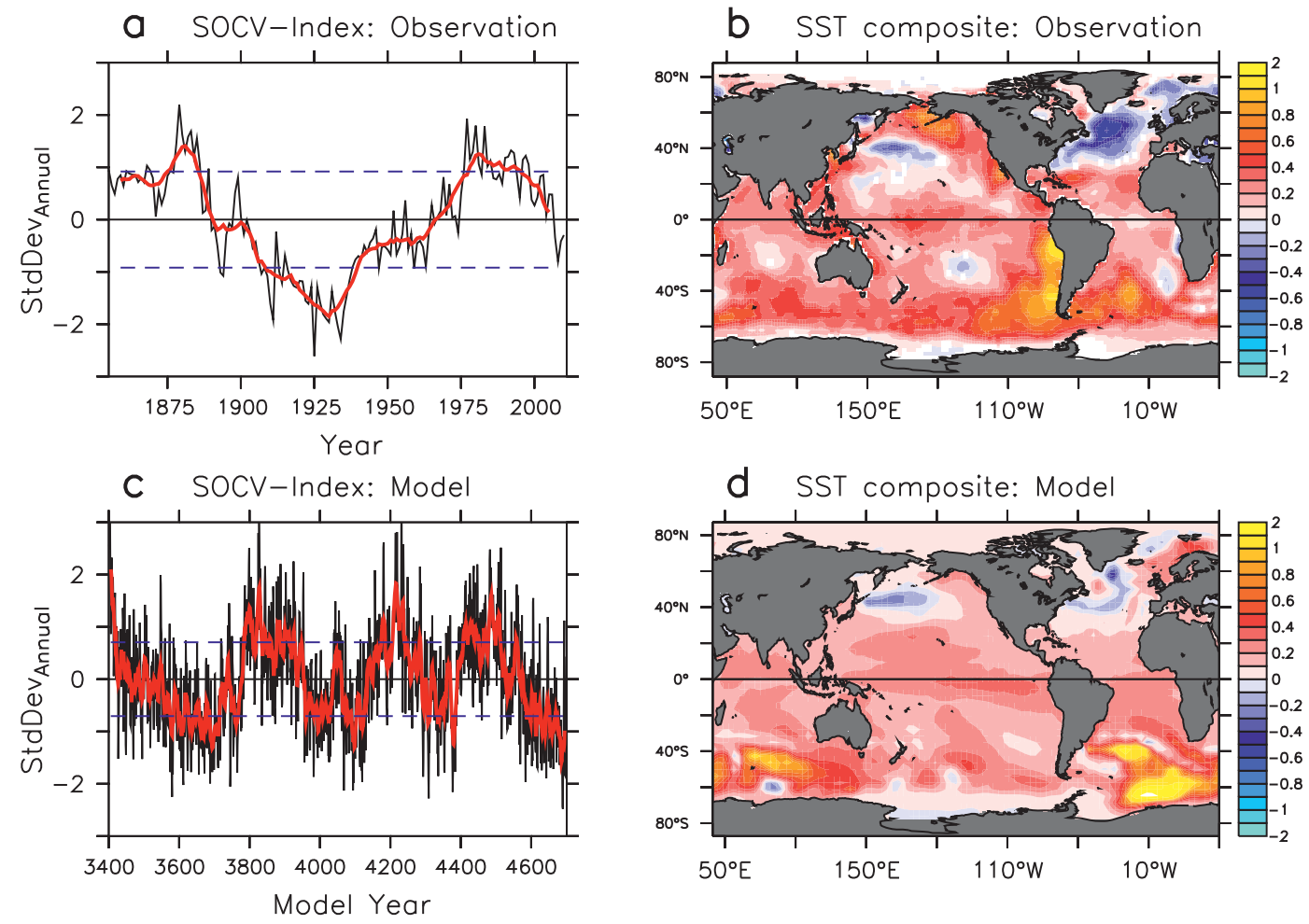

FIG. 2. The Southern Ocean SST depicts strong centennial variability in both the observations (a),(b) ERSST.v3b (1854-2010) and the simulation (c),(d) the KCM (1300 yr). (left) The SOCV index, which is defined by the annual SST anomalies zonally averaged over the latitude band $50^{\circ}-70^{\circ} \mathrm{S}$, detrended and normalized by long-term std dev. The removed trends amount to $0.11^{\circ} \mathrm{C}$ century ${ }^{-1}$ (observations) and $0.01^{\circ} \mathrm{C}$ century ${ }^{-1}$ (simulation). The std dev computed from the annual mean (after detrending) amounts to $0.14^{\circ} \mathrm{C}$ (observations) and $0.18^{\circ} \mathrm{C}$ (simulation). (right) SST composite pattern $\left({ }^{\circ} \mathrm{C}\right)$ showing the differences of high minus low SOCV index. High (low) index years are defined as years with an SOCV index greater (smaller) than plus (minus) one std dev (blue dashed lines) derived from the 11-yr running meanfiltered SOCV index (red lines) shown in (a) and (c). The observed SST data are described in Smith et al. (2008).

studied, for example, the PDO or AMO. The Southern Hemisphere low-frequency internal variability received relatively little attention likely due to a dearth of longterm observations, although some remarkable climate trends were observed there during the late twentieth and early twenty-first centuries, as described above. One possible explanation for the lack of a strong Southern Ocean surface warming is the strong vertical mixing in the Southern Ocean. However, when forced by estimates of observed external forcing the climate models, which participated in phase 3 of the Coupled Model Intercomparison Project (CMIP3), in the ensemble mean simulate surface warming everywhere over the Southern Ocean during 1979-2005 (Hegerl et al. 2007, their Fig. 9.6), whereas surface cooling was observed over large parts of the Southern Ocean during this time. The same holds for the Antarctic sea ice extent, which is simulated to retreat during the recent decades by most CMIP5 models as discussed by Zunz et al. (2013). The differences between the models and observations could be caused by internal variability, which can temporarily offset the effects of global warming. In this case, the multimodel mean cannot capture the observed variability, as the multimodel mean is only an estimate of the forced variability.

There is limited evidence of large-scale changes in temperature and precipitation on long time scales in the Southern Hemisphere climate record. Le Quesne et al. (2009) investigated more than 350 tree-ring cores and combined them into three tree-ring chronologies, which strongly correlate with instrumental precipitation in Santiago, Chile. Based on these records, a 712-yr precipitation reconstruction was developed. A mode with a period of about $200 \mathrm{yr}$ was extracted by singular spectral analysis (SSA), which explains $11.6 \%$ of the variance and captures the long-lasting dry and wet periods over the last 7 centuries. Cook et al. (2000) found evidence for enhanced centennial variability in a tree-ring-based Tasmanian summer temperature reconstruction of the last $3600 \mathrm{yr}$. They also examined warm-season SSTs, averaged over the southern Indian Ocean, from a 1400-yr control integration of the Hadley Centre coupled model, version 2 (HadCM2). At multidecadal and century 
time scales, the model SSTs have band-limited spectral features that are similar to those seen in the tree-ring reconstruction. Although centennial variability in the Southern Hemisphere is well documented from a number of paleo records, it remains unclear what the relative roles of external (forced) and internal (unforced) variability on these long time scales are and whether there are any distinct periodicities that stand out above the red background spectrum.

Could the variability of Southern Ocean deep convection be responsible for the documented centennial changes during the last few millennia and also for some fraction of decadal changes seen in recent history? Park and Latif (2008) describe pronounced Southern Hemisphere centennial variability in a control integration of the Kiel Climate Model (KCM). Martin et al. (2013) explained the centennial time scale (Fig. 2c) by the slow accumulation of heat advected into the Weddell Sea at middepth by the lower limb of the Atlantic meridional overturning circulation (AMOC). Galbraith et al. (2011) report pronounced long-term variability in Weddell Sea deep convection from another global climate model [Geophysical Fluid Dynamics Laboratory Climate Model, version 2.1 (GFDL CM2.1)]. Delworth and Zeng (2012), however, suggest a mechanism in that model that seems to differ from the mechanism operating in the $\mathrm{KCM}$. If supported by further research, the existence of significant internal centennial variability independent of its origin would have important implications for the climate of the twentieth and twenty-first centuries, regionally and possibly also globally.

This paper is a follow-up study of the work presented by Martin et al. (2013), who described the mechanism of the SOCV in two versions of the Kiel Climate Model. Here, we basically concentrate on the comparison of these model results with observational data and the spatial patterns associated with the SOCV in the model. Section 2 gives a brief overview of the data used in this study and the KCM. Southern Ocean sector surface temperature centennial variability is described from the instrumental SSTs and a tree-ring-based Tasmanian summer temperature reconstruction in section 3 . The model results are presented in section 4 , where we focus on the spatial patterns in both the ocean and atmosphere. The paper finishes with some concluding remarks in section 5 .

\section{Data and model}

\section{a. Data}

We use the instrumental SSTs from ERSST.v3b provided by the National Oceanic and Atmospheric
Administration (NOAA). The SSTs are not very reliable during the presatellite era in some regions, especially in the Southern Hemisphere. Moreover, the SST reconstruction is much too short to study centennial variability in detail. Therefore, Tasmanian summer surface air temperature reconstructions of the last $3600 \mathrm{yr}$ as described by Cook et al. (2000) were additionally obtained (http://www.ncdc.noaa.gov/paleo/recons.html). Again, there are large uncertainties in the reconstruction and it is unclear how well the tree-ring data record Southern Ocean centennial variability. Therefore, we would like to point out from the very beginning that a verification of the model centennial variability with observations will remain inconclusive to some extent. SLP data were obtained from the National Centers for Environmental Prediction-National Center for Atmospheric Research (NCEP-NCAR) reanalysis project (Kalnay et al. 1996). Sea surface salinities (SSSs) are taken from the National Oceanographic Data Center (NODC) World Ocean Atlas 1998 (WOA98) data provided by the NOAA/Office of Oceanic and Atmospheric Research (OAR)/Earth System Research Laboratory Physical Sciences Division (ESRL PSD; http://www.esrl.noaa.gov/psd/data/gridded/ data.nodc.woa98.html). [Antarctic sea ice thickness data presented in Worby et al. (2008) were obtained from http://aspect.antarctica.gov.au/data.]

\section{b. Model}

The SOCV and its global impacts are investigated further by analyzing a 1300-yr-long control integration of present-day climate conditions of the KCM (Park et al. 2009). The KCM consists of the ECHAM5 atmospheric general circulation model (AGCM) on a T31 $\left(3.75^{\circ} \times 3.75^{\circ}\right)$ horizontal grid coupled to the Nucleus for European Modelling of the Ocean (NEMO) oceansea ice $\mathrm{GCM}$ on a $2^{\circ}$ Mercator mesh with $0.5^{\circ}$ meridional resolution in the equatorial region. No form of flux correction or anomaly coupling is used. Further details are given in Park et al. (2009). The net southward transport at $30^{\circ} \mathrm{N}$, defined as the difference between the extremes of the overturning streamfunction in the upper North Atlantic Deep Water (NADW) cell and the lower Antarctic Bottom Water (AABW) cell, varies between 15 and 20 Sverdrups (Sv; $1 \mathrm{~Sv} \equiv 10^{6} \mathrm{~m}^{3} \mathrm{~s}^{-1}$ ). The northward transport of $\mathrm{AABW}$ in the Atlantic at $30^{\circ} \mathrm{S}$ varies between 2 and $7 \mathrm{~Sv}$. The KCM displays a rich spectrum of internal variability. In particular, the model simulates multidecadal SST variability in the North Atlantic and North Pacific Oceans with realistic period and spatial structure (Park and Latif 2010). The version used here has a more realistic representation of Antarctic sea ice than the original model version used by Park and Latif (2008) but like the previous version simulates pronounced 


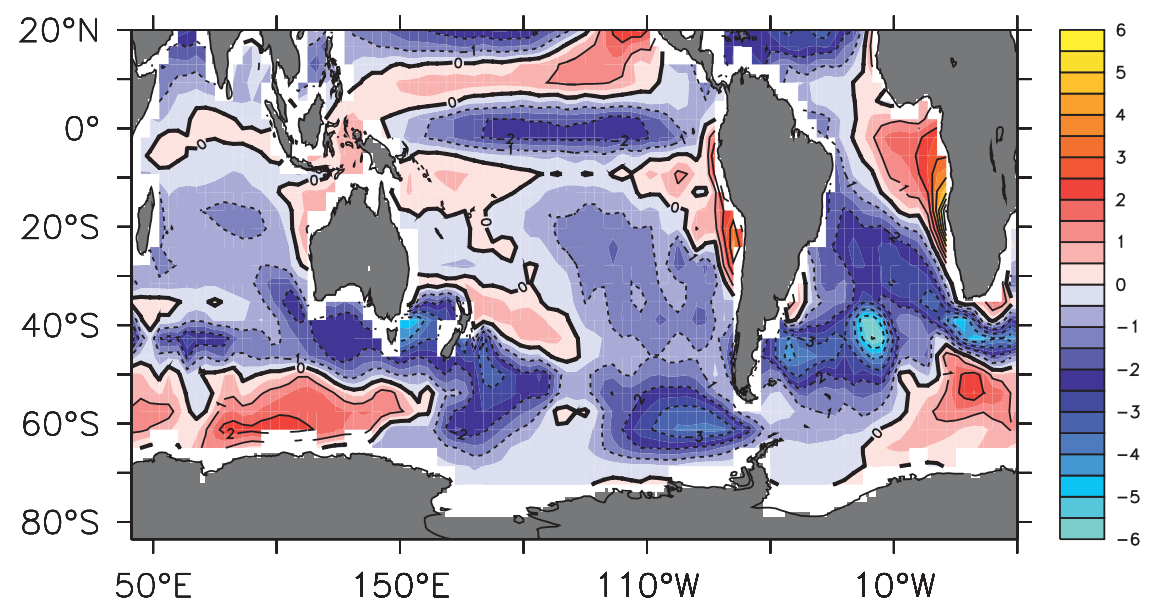

FIG. 3. The model SST bias $\left({ }^{\circ} \mathrm{C}\right)$ calculated with respect to the period 1970-99 from the ERSST.v3b observations and determined from the last $1000 \mathrm{yr}$ of the integration with the $\mathrm{KCM}$. The contour interval is $1^{\circ} \mathrm{C}$, while shading intervals amount to $0.5^{\circ} \mathrm{C}$. Dashed contours denote negative values.

SOCV (Figs. 2c,d). Additional information about the representation of the sea ice and SOCV mechanism can be found in Martin et al. (2013).

The KCM suffers from several biases. The SST bias in the tropics and Southern Hemisphere was computed from the last $1000 \mathrm{yr}$ of the integration with respect to the observed SSTs of 1970-99 taken from ERSST.v3b (Fig. 3). The size of the SST bias, which can reach several degrees Celsius in some regions, is typical for current generation climate models (Randall et al. 2007). The simulated Southern Ocean SSS is compared with the Levitus et al. (1998) climatology in Fig. 4. There is a general tendency of the model to simulate too low SSSs. Most striking are the much too fresh conditions in the Bellingshausen, Amundsen, and Ross Seas in the region $90^{\circ}-120^{\circ} \mathrm{W}$. This fresh bias is limited to the upper ocean (not shown) and may suppress deep convection similar to that in the Weddell Sea. Likely reasons for the bias are too strong precipitation, runoff, and sea ice melt. While precipitation minus evaporation $(P-E)$ is positive everywhere in the southern part of the Southern Ocean in the annual average and there are more coastal grid cells with strong runoff upstream of the Ross Sea than upstream of the Weddell Sea, we speculate that sea ice melt is the dominating cause. The spatial distribution of the SSSs in the greater Ross Sea region is well pattern correlated with the sea ice melt in austral spring $(r=$ $0.65)$, whereas the SSS and the $P-E$ pattern are only weakly correlated year-round $(r \leq 0.2)$. Furthermore, the freshwater flux into the ocean from sea ice melt in

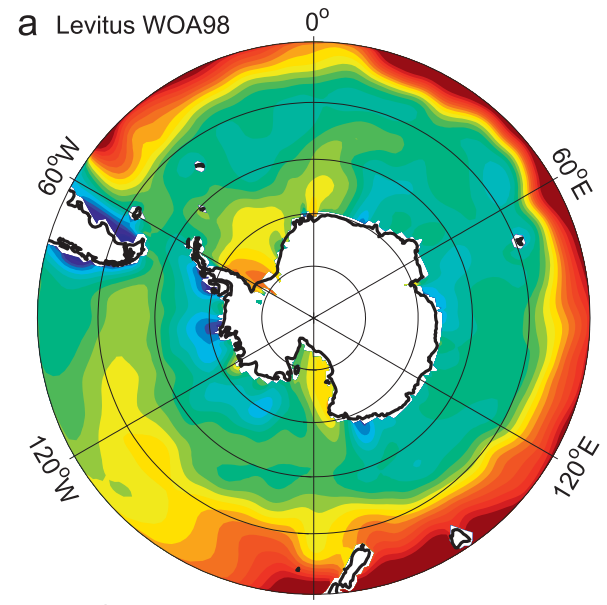

sea surface salinity

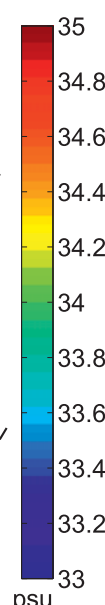

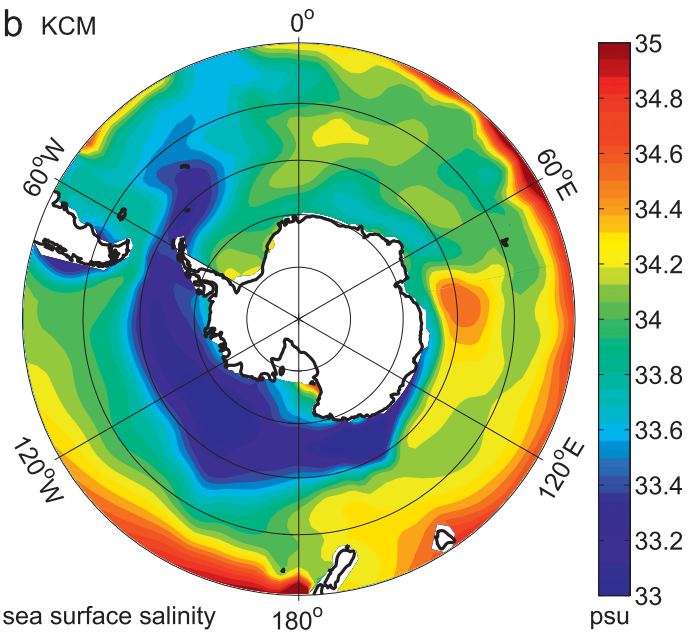

FIG. 4. Annual-mean SSS (psu) from (a) observations (Levitus et al. 1998) and (b) a 1000-yr mean from the KCM. 


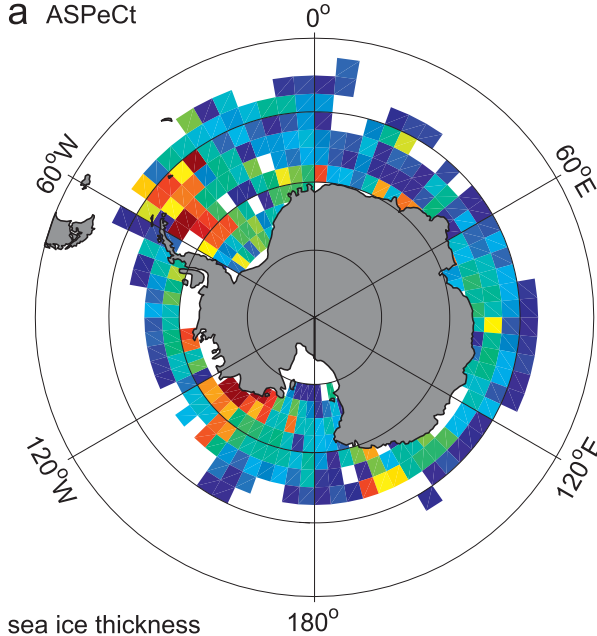

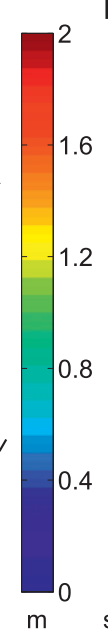

$\mathrm{m}$ b KCM

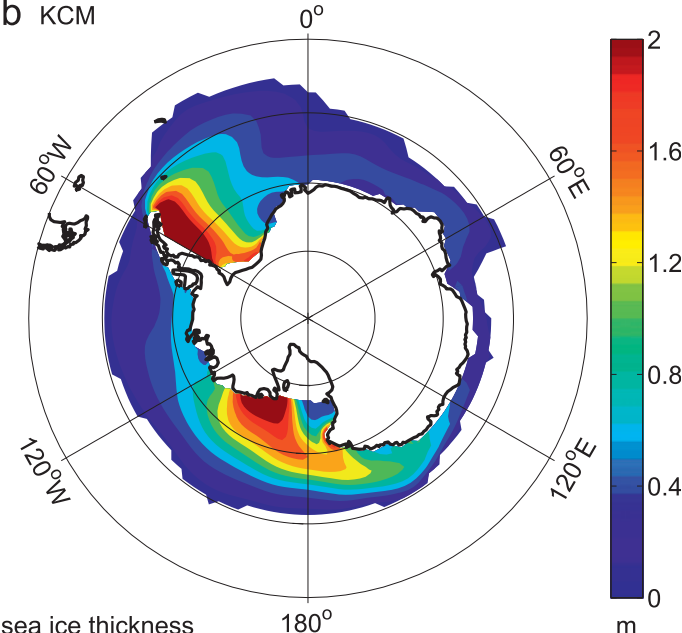

FIG. 5. Annual-mean Antarctic sea ice thickness (m) from (a) observations (Worby et al. 2008) and (b) a 1000-yr mean from the KCM.

austral spring is $2-3$ times greater than the rather constant $P-E$ flux.

The Antarctic sea ice thickness is compared with observations in Fig. 5. Observational records collected by Worby et al. (2008) report an annual average of $0.62 \pm$ $0.67 \mathrm{~m}$ (Fig. 5a). The KCM simulates an Antarctic sea ice cover with an annual long-term-mean thickness of $0.69 \pm 0.72 \mathrm{~m}$ (Fig. 5b). Although the sea ice thickness distribution in the KCM compares reasonably well with the observations, the amount of thick ice in and east of the Ross Sea is considerably overestimated, and this may also contribute to the surface ocean freshening over the years.

\section{Southern Ocean centennial surface temperature variability}

As described above, an index of the SOCV is defined as the zonal average SST over the region $50^{\circ}-70^{\circ} \mathrm{S}$ (Fig. $2 \mathrm{a})$. This region was chosen because it did not exhibit a strong warming during the recent decades and because both the PDO and AMO do not strongly project on this index (Park and Latif 2012). The SOCV index depicts pronounced centennial variability during the instrumental period, with the maxima around the mid1870s and mid-1970s. The global SST anomaly pattern associated to the SOCV index, as obtained from composite analysis (see caption of Fig. 2 for details), is mostly governed by anomalies of one sign (Fig. 2b), indicating that the SOCV has a projection on global average SST. Anomalies of the opposite sign are seen only in the North Pacific and North Atlantic Oceans. The rapid increase of the SOCV index during the mid-1970s (Fig. 2a) concurred with the so-called climate shift in the
Pacific Ocean (Trenberth and Hurrell 1994; Graham 1994), which was characterized by an anomalously warm equatorial Pacific and an anomalously cold North Pacific. Similar anomalies are seen in the SOCV index pattern (Fig. 2b). Although the origin of the climate shift is assumed to primarily have been either in the tropical Pacific or North Pacific, the Southern Ocean may have contributed. On the other hand, Meehl et al. (2009) find evidence for external forcing also playing a role in driving the mid-1970s climate shift in the Pacific. Another significant "shift" occurred in the 1970s in the midand high latitudes of the Southern Ocean region (Hurrell and van Loon 1994), with lower SLP during the 1980s than in the 1970s (see also Fig. 9, described in greater detail below). The latter was associated with a cooling of the South Pacific. We return to this point below when discussing the model results and comparing them with the data. The SOCV index dropped after the mid-1970s and was well below normal during the most recent years (Fig. 2a).

The instrumental SST data are poor in the Southern Hemisphere and the record length is much too short to thoroughly study long-term variability. In particular, the SOCV index pattern derived from the instrumental observations (Fig. 2b) is subject to large uncertainties. The existence of pronounced centennial variability in the Southern Ocean sector is supported by the Tasmanian summer temperatures of the last $3600 \mathrm{yr}$ as reconstructed from tree rings by Cook et al. (2000). Here, we reproduce some of the results of Cook et al. (2000) and show in Fig. 6a the reconstructed Tasmanian summer temperatures. We compare the latter with the annual SOCV index during the instrumental record (Fig. 6b). Although there are a number of differences on interannual-to-decadal time 


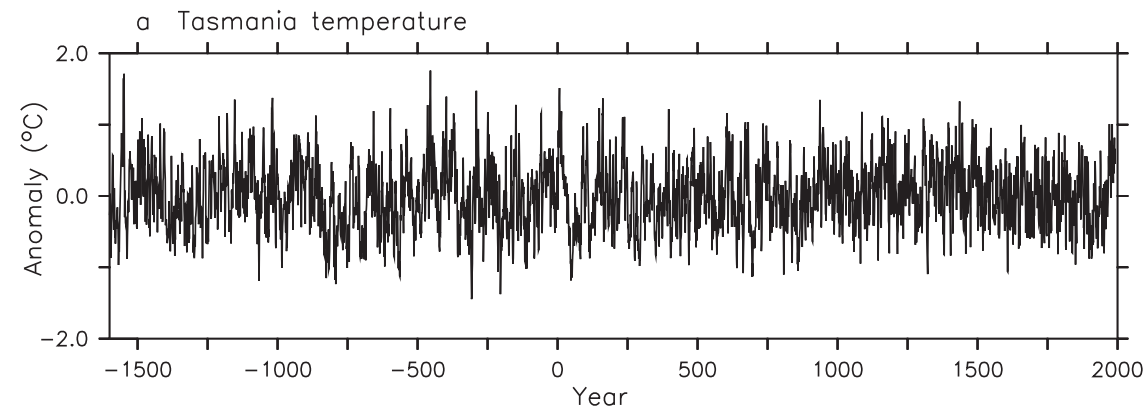

b Tasmania temperature vs. ERSSTv3b SOCV-Index

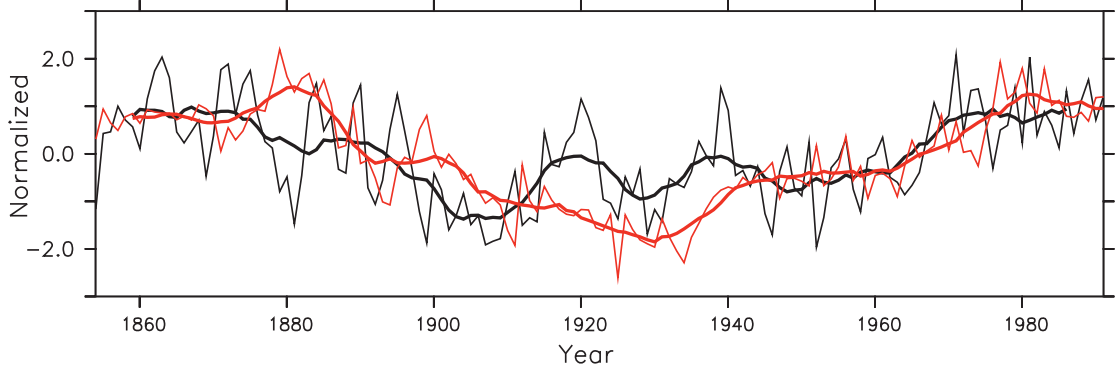

c Tasmania temp. Wavelet spectrum

d Global spectrum
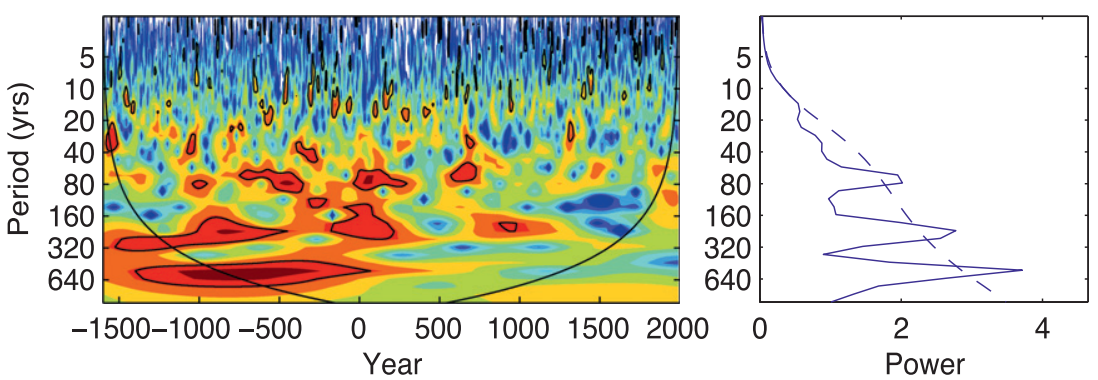

FIG. 6. (a) Tasmanian warm-season (November-April) temperature $\left({ }^{\circ} \mathrm{C}\right)$ reconstruction from Cook et al. (2000). (b) Comparison of the reconstruction (black) with the annual SOCV Index from the instrumental observations (red). (c) Wavelet spectrum and (d) global spectrum of the Tasmanian summer temperatures using the method of Torrence and Compo (1998). The thick black contours in (c) and the dashed line in (d) indicate a 95\% confidence level using a red-noise background spectrum.

scales, the centennial variability, which is the topic of this study, is reasonably well captured by the reconstruction. More importantly, at centennial time scales there is clearly enhanced variability in the tree-ring temperatures (Cook et al. 2000, their Fig. 9b); although, tree-ring temperature reconstructions tend to underestimate the level of centennial variability. Significant peaks above the $99 \%$ level were found by Cook et al. (2000) at periods of about $200-300$ and $500 \mathrm{yr}$. We basically reproduce these periodicities by applying wavelet analysis (Figs. 6c,d), supporting the previous results of Cook et al. (2000). It should be mentioned, however, that the time scale strongly varies with the time during the treering record (Fig. 6c). The multidecadal peak (Fig. 6d) is also of interest here, as different versions of the KCM simulate SOCV with rather different time scales, indicating a strong sensitivity of the periodicity to the model formulation as discussed below (see Fig. 11, described in greater detail below). We conclude that the Tasmanian tree-ring data support the existence of centennial variability in the Southern Ocean sector surface climate, but it remains to be quantified what the relative roles of external (e.g., solar) forcing and internal variability in the different frequency bands are.

\section{Climate model results}

Consistent with the instrumental SSTs (Fig. 2a) and reconstructed Tasmanian summer temperature (Fig. 6), the model simulates pronounced SOCV (Fig. 2c). An SOCV index was computed from the model in the same way as from the observed SSTs. The standard deviation 

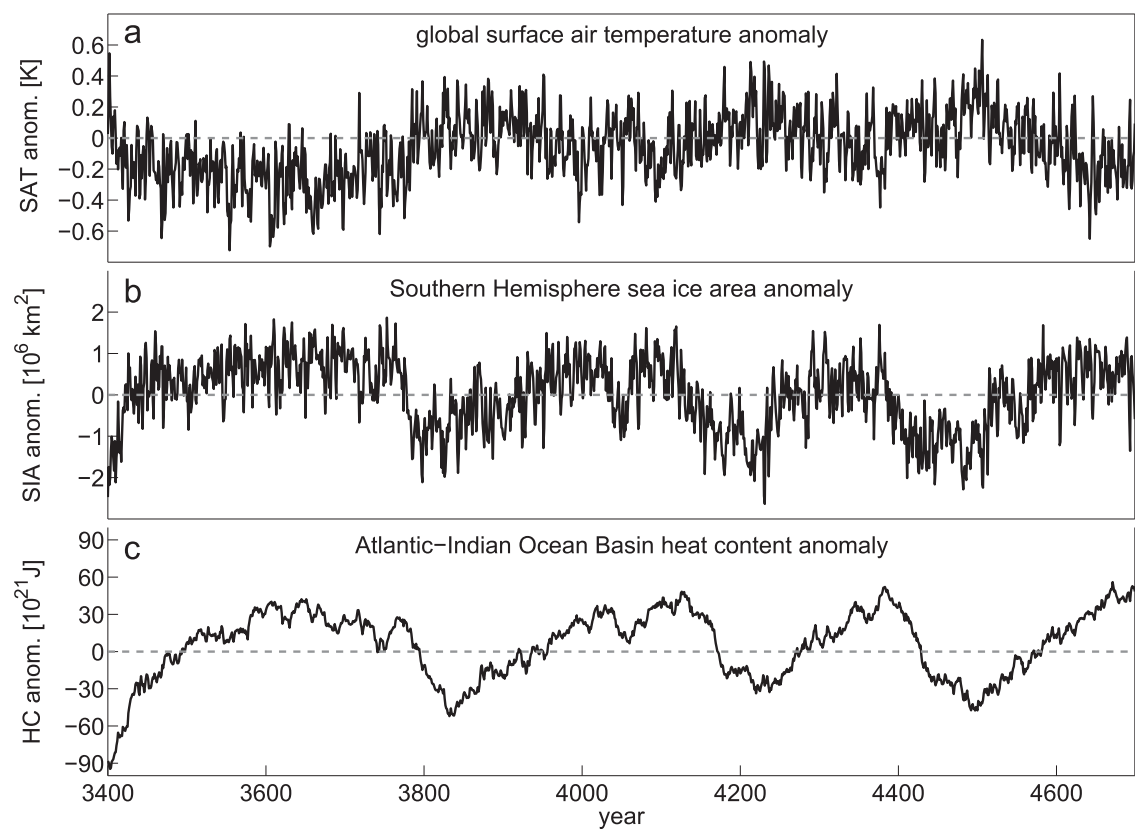

FIG. 7. The KCM simulation features pronounced centennial variability in the Southern Ocean sector, which is even seen in the (a) global-average SAT anomalies. The centennial variability is associated with variations in (b) Southern Hemisphere sea ice area and strongly linked to the oceanic heat content in the (c) Atlantic-Indian Ocean Basin. All three time series show annual-mean values of anomalies that are derived with respect to the model years 3800 4100 , which approximately cover one full period of the deep convection oscillation.

computed from the annual means amounts to $0.18^{\circ} \mathrm{C}$ for the model SOCV index, as opposed to $0.14^{\circ} \mathrm{C}$ for the SOCV index obtained from the instrumental SSTs (Fig. 2a). The model variability has the most power at periods of 300-400 yr. The SST variability is irregular, and the model also simulates, for instance, a 100-yr fluctuation during model years 4000-4100 (Fig. 2c), similar to that observed during the instrumental period (Fig. 2a). The correlation between the model SOCV index and the model Tasmanian SAT amounts to about 0.7 when using low-pass-filtered data (21-yr running means), which are significant at the $95 \%$ level. Moreover, cross-spectral analysis (not shown) reveals that there is highly significant coherence (above the 99\% confidence interval) between the model SOCV index and the model Tasmanian SAT at centennial time scales. The model results thus suggest that the Tasmanian tree rings may well record the SOCV.

The gross features of the model SOCV index pattern (Fig. 2d) are similar to those derived from the instrumental observations (Fig. 2b): most regions depict positive SST anomalies, while negative anomalies are seen in the North Pacific and North Atlantic Oceans. However, there are a number of noticeable differences between the model pattern and that derived from the instrumental data. Most importantly there is a strong warming off the west coast of South America in the pattern derived from the observations, which is not seen in the model pattern. Instead the model pattern depicts the strongest warming in the Weddell Sea region. Differences between model and instrumental data are to be expected for several reasons. First, the observational data quality is poor. Second, the observations resolve only one cycle of the centennial mode. Global climate variability is governed by many different processes, may they be internal or external, natural or anthropogenic. A single mode cannot account for all the observed variability during the short instrumental period, as the variability is a superposition of modes with different patterns and time scales. Many realizations of the centennial mode are needed to obtain its "true" pattern, which is one reason for using long control runs with global climate models. Third, the KCM is a coarse-resolution model and suffers from large biases in parts of the Southern Ocean [Figs. 3-5; see also Park et al. (2009)]. The model results should be therefore understood more as a conceptual framework that can help to guide interpretation of the sparse observations; we are not aiming at explaining all aspects of the observed variability during the last $160 \mathrm{yr}$.

The SOCV is clearly reflected in global-average SAT in the KCM (Fig. 7a), and it goes along with the rather 
rapid Southern Hemisphere sea ice area changes (Fig. 7b). Global-average SAT changes linked to the SOCV amount to a few tenths of a degree Celsius per century, while Southern Hemisphere sea ice area changes are of the order of $\pm 10 \%$ of the long-term-mean sea ice area, which varies between $9 \times 10^{6}$ and $11 \times 10^{6} \mathrm{~km}^{2}$ on these time scales. The SOCV is related to centennial-scale alternations between regimes with and without convective overturning in the Weddell Sea, which is described in detail by Martin et al. (2013). The model results support the conjecture that the occurrence of the Weddell Polynya could have been linked to the SOCV. We note, however, that the scale of the observed Weddell Polynya $\left(350000 \mathrm{~km}^{2}\right)$ was considerably smaller than the sea ice area changes in the Weddell Sea associated with the centennial variability in the KCM. The rather coarse ocean model resolution $\left(2^{\circ} \times 2^{\circ}\right)$ inhibits the explicit simulation of polynyas with such a relatively small spatial scale. Furthermore, the Weddell Polynya was observed only during three consecutive winters, which is inconsistent with the long time scale sea ice extent variability in the KCM. The main point we wish to convey here is that the occurrence of the Weddell Polynya during the mid-1970s could have been linked not only to surface but also to deep-ocean processes.

The Weddell Sea deep convection and sea ice decline in the $\mathrm{KCM}$ are stimulated by the buildup of heat in the Atlantic-Indian Ocean Basin (Fig. 7c), which primarily takes place at middepth between 1000 and $3000 \mathrm{~m}$ (Martin et al. 2013). The variations of the vertically integrated heat content amount to about $\pm 40 \times 10^{21} \mathrm{~J}$ in the Atlantic Ocean basin-Indian Ocean Basin, defined here as the region $40^{\circ}-90^{\circ} \mathrm{S}$ and $70^{\circ} \mathrm{W}-80^{\circ} \mathrm{E}$. The heat is provided by the lower branch of the AMOC, a mechanism previously described from uncoupled ocean model simulations (Mikolajewicz and Maier-Reimer 1990; Yin and Sarachik 1995; Pierce et al. 1995) and coupled climate model simulations (Santoso et al. 2006). During phases of deep convection, large amounts of heat are released to the atmosphere in the $\mathrm{KCM}$, similar to what was observed during the Weddell Polynya (Moore et al. 2002). This drives global atmospheric teleconnections in the model, which will be discussed below.

Deep-water warming in the Southern Ocean and a global-scale contraction of Antarctic Bottom Water was reported after the occurrence of the Weddell Polynya (Robertson et al. 2002; Purkey and Johnson 2010; Fahrbach et al. 2011; Purkey and Johnson 2012). We computed composites of temperature and salinity anomalies associated with the model SOCV index (Fig. 2c) at three vertical levels: 5, 1400, and $4250 \mathrm{~m}$ (Fig. 8). The same procedure was applied as that used in Fig. 2, but the sign was reversed as we are interested here in the model tendencies after the Weddell Sea deep convection stops: that is, the trends from the warm phase to the cold phase of the SOCV (low SOCV index minus high SOCV index). For instance, the SST (i.e., temperature at $5 \mathrm{~m}$ ) anomaly pattern shown in Fig. 8a is therefore by definition the same as that depicted in Fig. $2 d$ but with opposite signs. The model simulates a warming of almost the entire water column in the Weddell Sea after deep convection stopped there (Figs. 8c,e), with the exception of the surface layers that cool (Fig. 8a). The strongest subsurface warming is found at middepth (Fig. 8c), the model levels where the North Atlantic Deep Water accumulates in the Weddell Sea. A negative temperature anomaly is seen at this level farther to the north off the eastern coast of South America.

The warming at the lowest model level, at $4250 \mathrm{~m}$, is most pronounced in the Atlantic sector and the western Indian Ocean sector of the Southern Ocean (Fig. 8e), consistent with the deep temperature measurements of the last decades. We conclude that part of the observed deep-sea warming in the Southern Ocean could be simply explained by the switch from a convective regime in the Weddell Sea during the mid-1970s to a nonconvective regime thereafter. We note that the composite (low SOCV index minus high SOCV index) deep-ocean warming in the KCM amounting to a few tenths of a degree (Fig. 8e) considerably exceeds the warming observed in the Weddell Gyre during 1984-2008 as reported by Fahrbach et al. (2011).

The surface cooling of the Weddell Sea is accompanied by surface freshening (Fig. 8b). At middepth $(1400 \mathrm{~m})$, the model depicts a positive salinity anomaly of the order of $0.01 \mathrm{psu}$, with a maximum of $0.05 \mathrm{psu}$ in the eastern Weddell Sea near the Greenwich meridian (Fig. 8d). As in the temperature anomaly pattern at this level, negative anomalies are seen farther to the north off the eastern coast of South America. At the bottom level, at $4250 \mathrm{~m}$, the warming goes along with an increase of salinity in the eastern Weddell Sea and the western Indian Ocean sector of the Southern Ocean in the KCM (Fig. 8f), amounting to about 0.01-0.02 psu. The model simulates a weak freshening in the western part of the Weddell Sea and in the Pacific sector of the Southern Ocean. Observations indicate a rapid freshening of the Indian and Pacific sources of Antarctic Bottom Water during the last decades (Rintoul 2007), where the model generally shows only a little change in salinity, with the exception of the western Indian Ocean sector, which depicts enhanced salinity (Fig. 8f).

The observed changes are a result of both external and internal factors. The common notion is that global warming in response to anthropogenic greenhouse gas emissions drives surface freshening in the high-latitude 

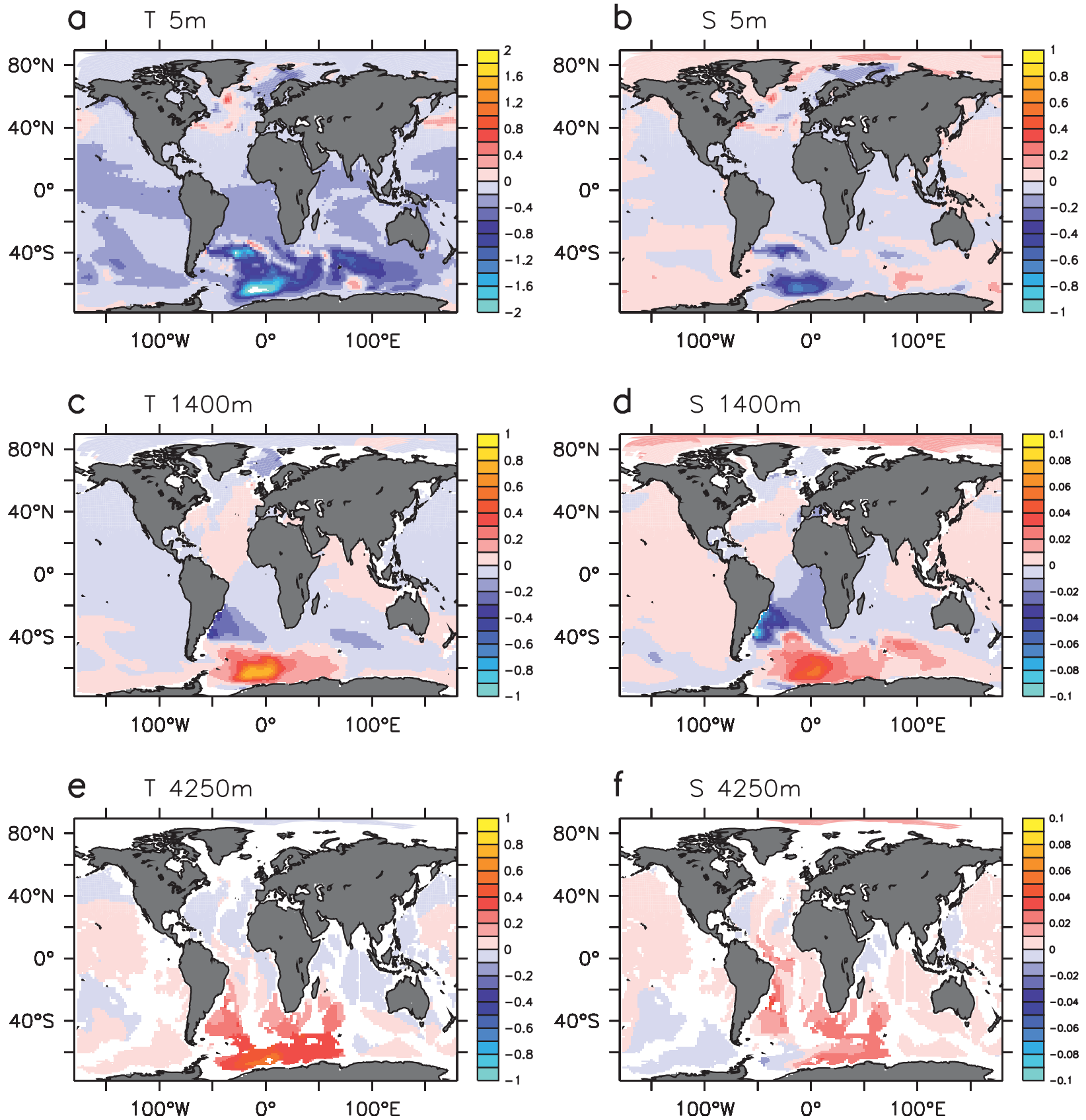

FIG. 8. In the KCM, the Southern Ocean centennial variability is associated with potential temperature $\left({ }^{\circ} \mathrm{C}\right)$ and salinity (psu) changes throughout the water column. Composite (low - high) anomaly patterns using the SOCV index shown in Fig. 2c of (a) SST (5-m ocean temperature), (b) SSS (5-m salinity), (c) temperature at $1400 \mathrm{~m}$, (d) salinity at $1400 \mathrm{~m}$, (e) temperature at $4250 \mathrm{~m}$, and (f) salinity at $4250 \mathrm{~m}$.

ocean. Near Antarctica, this could be linked to shelf ice melt. The freshening signal can be quickly transmitted to the abyssal ocean in deep-water formation regions. The model results discussed here are only an example of internal variability that may have contributed to the changes observed in the Southern Ocean. Different decadal salinity trends were observed in the different water masses in the Weddell Sea as reported by Fahrbach et al.
(2011). While the deepest water mass, the bottom water, exhibited a freshening trend since 1985, the deep water located above the bottom water showed an increase in salinity. We speculate that the freshening of the bottom water is linked to surface freshening, which is transmitted to the abyssal ocean by shelf convection. This type of freshening of the Weddell Sea Bottom Water cannot be simulated by our model: first, because the model does not 

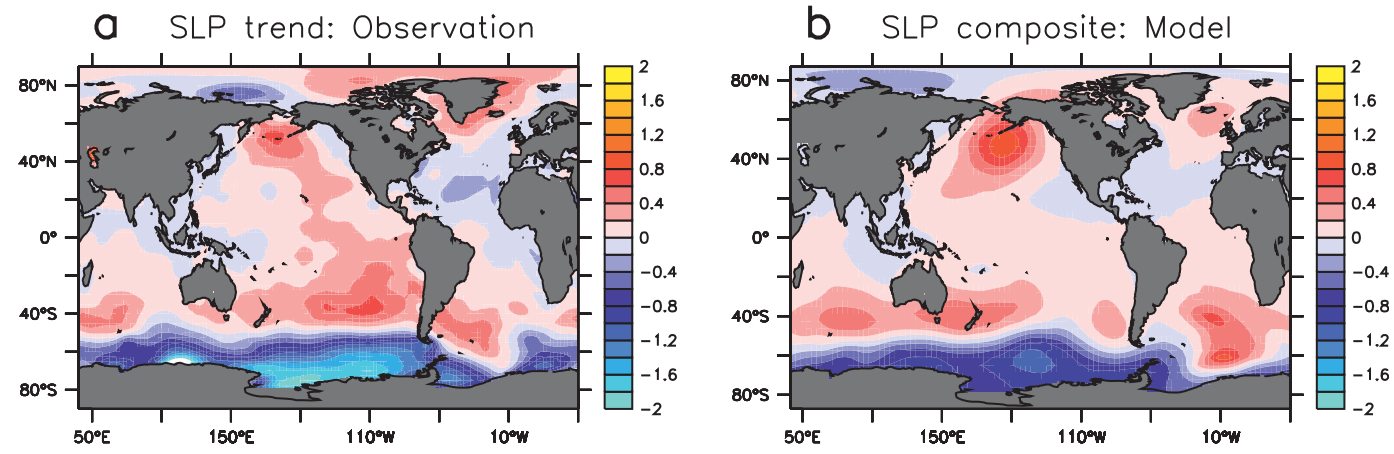

FIG. 9. The KCM simulates global teleconnections in association with the Southern Ocean centennial variability. (a) The observed SLP trend 1975-2010 (hPa decade ${ }^{-1}$ ). (b) The model composite (low - high) SLP anomaly pattern $(\mathrm{hPa})$ using the SOCV index shown in Fig. 2c. The SLP data are from Kalnay et al. (1996). The global average was subtracted from both patterns.

carry ice shelves; second, because of its coarse resolution the model does not simulate slope convection; and third, because external forcing in the form of increasing greenhouse gas concentrations is not included. The increase in the salinity of the Weddell Sea Deep Water observed during the last decades, on the other hand, may be due to internal variability, specifically the halt in Weddell Sea deep convection as suggested by the model. The salinity changes, like those in temperature, are considerably larger than the changes measured in the Weddell Sea during the last decades (Fahrbach et al. 2011). It should be kept in mind, however, that the model composites reflect the full range of the centennial variability (i.e., the peak-to-peak changes).

In the $\mathrm{KCM}$, the switch from the warm to the cold phase of the SOCV is associated with changes in the Southern Hemisphere low-level atmospheric circulation and global teleconnections. We computed an SLP anomaly composite pattern from the KCM, again using the SOCV index shown in Fig. 2c, and compare the model SLP pattern (low - high; i.e., cold - warm SOCV index) with the observed (NCEP) SLP trend pattern 1975-2010 (Fig. 9a), a period that also represents a switch from a convecting (warm) to a nonconvecting state (cold) in the Weddell Sea. The two global SLP patterns exhibit a pattern correlation of 0.74 . Consistent with the observations, an anomalously strong meridional SLP gradient is simulated over the midlatitudes of the Southern Hemisphere (Fig. 9b). Our model results support the conjecture that internal centennial variability originating in the Southern Ocean did contribute not only to the observed SST but also to the observed SLP trends. Moreover, the low-frequency variations of the SAM index (not shown; see Visbeck 2009) are basically anticorrelated with those of the SOCV index, with a decline (increase) of the SAM index (SOCV index) from the 1930s to the 1970s and an increase (decrease) of the SAM index (SOCV index) thereafter, suggesting some ocean-atmosphere coupling on a long time scale. External forcing alone (e.g., Arblaster and Meehl 2006; Arblaster et al. 2011; Thompson et al. 2011) may thus not completely explain the observed SLP trends in the Southern Ocean sector during the recent decades.

The phase change in the model is associated with $\mathrm{La}$ Niña-like (i.e., anomalously cold) conditions in the equatorial Pacific (Fig. 8a). Interestingly, reduced warming relative to the global average warming was observed during the recent decades (Fig. 1). However, the cooling extends too far westward in the model composite (a typical bias in climate models), which is due to an overly strong cold tongue extending too far westward. External forcing was proposed by Cane et al. (1997) to explain the equatorial Pacific cooling tendency during the recent decades. The model results suggest that there may be also a contribution to the equatorial Pacific cooling coming from the SOCV. The Aleutian low and, to a lesser extent, the Icelandic low weaken in association with the phase change of the centennial mode in the model (Fig. 9b). This is also consistent with the observations of the last decades (Fig. 9a). We would like to point out again that the observed trend pattern is a superposition of several internal modes and externally forced variability. The good correspondence of the observed changes with the model patterns may be thus partly coincidental.

Figure 10 depicts the anomaly patterns of several other model variables in terms of composites with respect to the model SOCV index (Fig. 2c), computed in the same way as the SST composite shown in Fig. $2 \mathrm{~d}$. These patterns therefore represent the polarity of the anomalies during the warm phase of the SOCV. As expected, the 2-m temperature composite (Fig. 10a) is very similar to that of the SST (Fig. 2d), with the strongest 
a $2-\mathrm{m}$ temperature $\left({ }^{\circ} \mathrm{C}\right)$

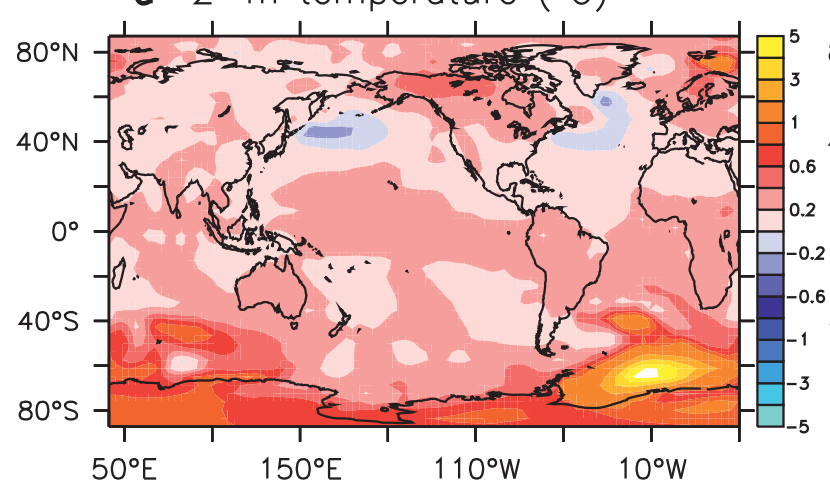

C Precipitation ( $\mathrm{mm} /$ day)

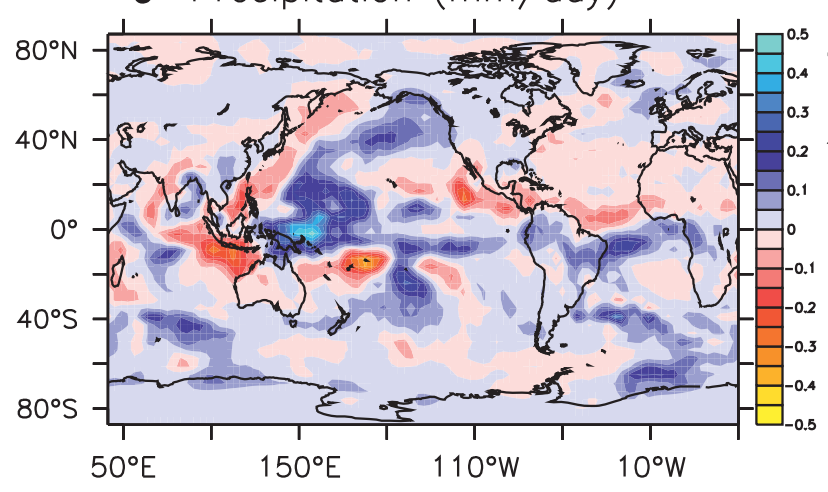

e Net surface heat flux $\left(\mathrm{W} / \mathrm{m}^{2}\right)$

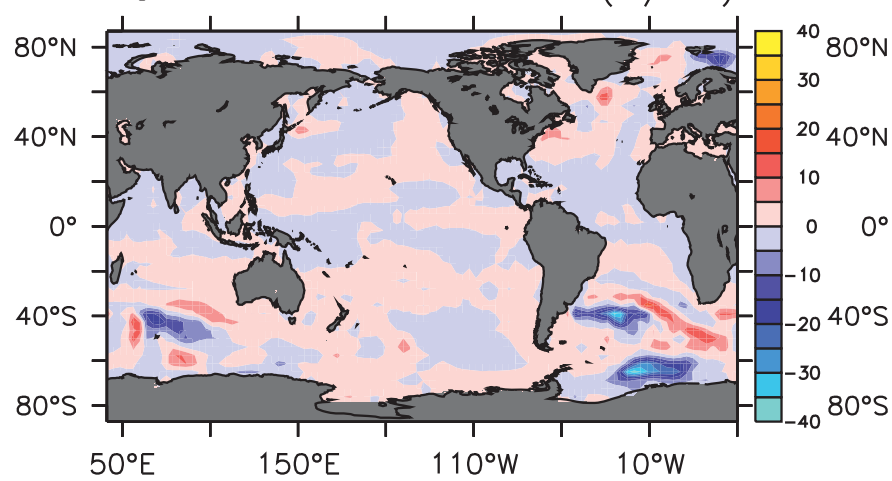

b $500 \mathrm{GPH}(\mathrm{gpm})$

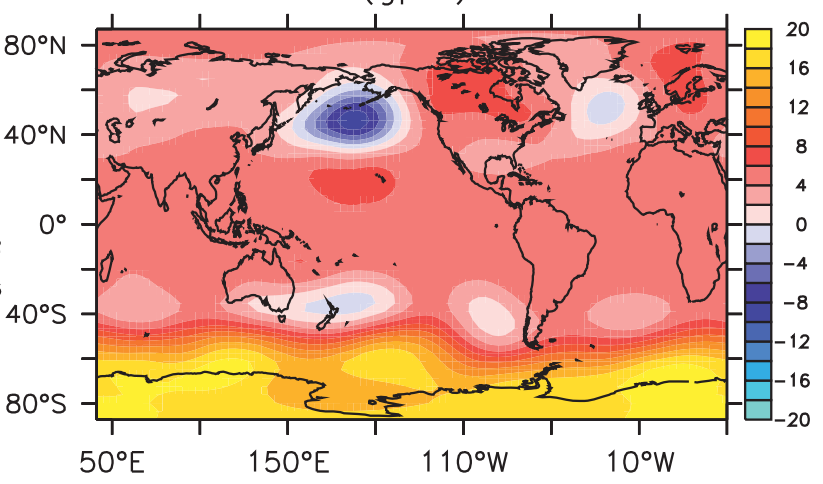

d Sea lce (\%)

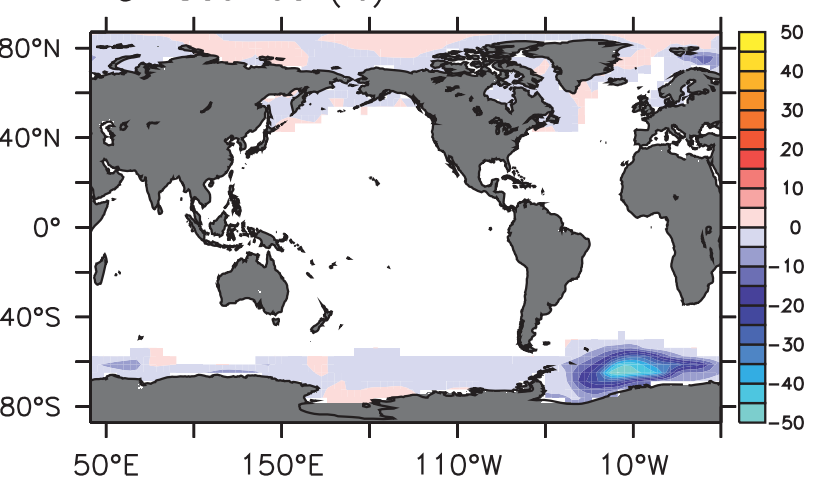

f $10-m$ wind $(\mathrm{m} / \mathrm{s})$, Wind stress

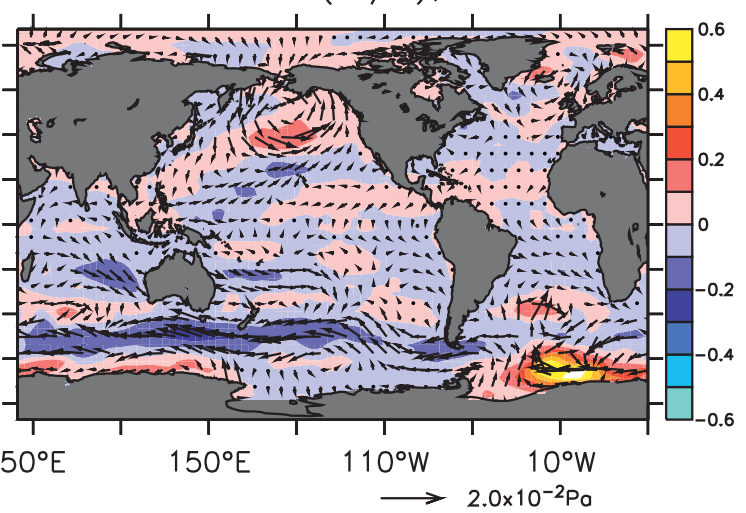

FIG. 10. Composites associated with the centennial variability for different model variables (the method is same as in Fig. 2d): (a) 2-m temperature $\left({ }^{\circ} \mathrm{C}\right)$, (b) 500-hPa geopotential height $(\mathrm{gpm})$, (c) precipitation $\left(\mathrm{mm} \mathrm{day}^{-1}\right)$, (d) sea ice fraction $(\%)$, (e) net surface heat flux ( $\mathrm{W} \mathrm{m}^{-2}$; positive anomalies indicate heat going into the ocean), and (f) $10-\mathrm{m}$ wind speed ( $\mathrm{m} \mathrm{s}^{-1}$; color shading) and surface wind stress (Pa; arrows).

warming in the Weddell Sea region. The anomaly pattern of the $500-\mathrm{hPa}$ geopotential heights (Fig. 10b) is rather similar to the inverted SLP anomaly composite (Fig. 9b), suggesting a barotropic vertical structure in most regions. The strongest positive $500-\mathrm{hPa}$ height anomalies are simulated over Antarctica and the southern part of the Southern Ocean. The most pronounced signal on the Northern Hemisphere is the strong negative height anomaly over the North Pacific representing an intensification of the Aleutian low. Enhanced precipitation is simulated over the region of strongest surface warming in the Weddell Sea (Fig. 10c). However, the strongest precipitation signal is found over the tropical western Pacific and eastern Indian Ocean. This 
dipole pattern is reminiscent of an El Niño-forced rainfall anomaly pattern, with enhanced rainfall stretching from the tropical western Pacific eastward along the equatorial Pacific and reduced rainfall in the Indian Ocean. As the precipitation is linked to upperlevel diabatic heating of the atmosphere, we believe that the intensification of the Aleutian low is forced by the tropical Pacific. The positive rainfall signal over the North Pacific probably can be attributed to the stronger Aleutian low. A southward displacement of the intertropical convergence zone is simulated over the tropical Atlantic.

A strong sea ice reduction is seen in the Weddell Sea during the warm phase of the SOCV (Fig. 10d), as discussed above. The net surface heat flux pattern is rather noisy (Fig. 10e) but also has the strongest change in the Weddell Sea region. The sign of the net surface heat flux anomalies in this region is such that the atmosphere tends to damp the surface warming. Finally, Fig. 10f shows the anomaly patterns of the surface wind stress and lowlevel $(10 \mathrm{~m})$ wind speed. Overall, the changes in these two quantities are consistent with the pressure changes. A clear signal in the surface westerlies over the Southern Ocean is seen, with weakened (intensified) winds during the warm (cold) phase of the SOCV. Again, the strongest changes are seen in the Weddell Sea, with highly enhanced wind speed over the region of strongly reduced sea ice.

\section{Concluding remarks}

The Southern Ocean sea surface temperature depicts a pronounced centennial variability during the instrumental period. Furthermore, a multimillennial tree-ring-based reconstruction of Tasmanian summer temperatures reveals significantly enhanced variability at centennial time scales. A 1300-yr-long control integration of the Kiel Climate Model (KCM) depicts similar Southern Ocean centennial variability (SOCV), which by definition is internal and does not require external forcing. We hypothesize that some of the remarkable trends observed during the recent decades in the Southern Hemisphere have contributions from such centennial variability. The Weddell Polynya of the mid-1970s and the concurrent deep convection in the Weddell Sea, for instance, may reflect the height of the warm phase of the SOCV. When the Weddell Sea deep convection halts in the model, the Antarctic sea ice cover expands. This has been observed during the recent decades, and the existence of internal centennial variability in the Southern Hemisphere could partly explain the rather different evolution of Arctic and Antarctic sea ice extent. The centennial mode did undergo a phase reversal from its positive phase during the mid-1970s to its negative phase during the recent years, thereby not only cooling the Southern Ocean sector but also retarding global-average surface air temperature. The cease of Weddell Sea convection in the model is followed by deep-sea warming in the Southern Ocean. A deep-sea warming in the Southern Ocean has been observed during the recent decades, suggesting that the warming could have a contribution from the SOCV. The increase of the southern annular mode (SAM) also could be linked to the SOCV, as the SAM intensifies in the model after deep convection stops in the Weddell Sea. In summary, the model results may provide a kind of null hypothesis for the interpretation of some of the recent Southern Hemisphere decadal trends observed in the Southern Ocean, Antarctic sea ice, and low-level atmospheric circulation over the Southern Ocean.

A cautionary note should be made at this point. When making a reference to the observed trends during the recent decades, one has to keep in mind the additional effects of external forcing. In the real world, unforced and forced variability go side by side. For instance, the enhanced oceanic freshwater input in response to anthropogenic warming from ice melt or changes in the hydrological cycle can be rapidly communicated to the abyssal ocean in the high-latitude convection regions. Such forced processes by definition are not incorporated in control integrations of climate models that provide only unforced variability. We do not want to challenge previous studies that assigned an important role to external forcing in explaining some of the recent decadal trends. What we would like to point out here is that internal variability cannot be a priori neglected. Furthermore, the patterns of internal and external variability may be similar, which makes the detection of externally forced signals a challenge, especially on regional scales.

Pronounced internal centennial Northern Hemisphere SAT variability, in which the Atlantic meridional overturning circulation (AMOC) plays a prominent role, is simulated in another climate model (GFDL CM2.1; Delworth and Zeng 2012). In that model, upper-ocean salinity anomalies slowly propagate on a multidecadal time scale from the Southern Hemisphere into the North Atlantic sinking region and affect deep convection there, giving rise to the long time scale. Although the mechanism of centennial variability in the Delworth and Zeng (2012) simulation still needs further investigation, it appears to be rather different to the mechanism operating in the KCM. While deep convection in the subpolar North Atlantic plays an important role in Delworth and Zeng (2012), in the KCM Weddell Sea deep convection is crucial to produce the centennial variability and impacts the AMOC (Martin et al. 2013). However, there is 

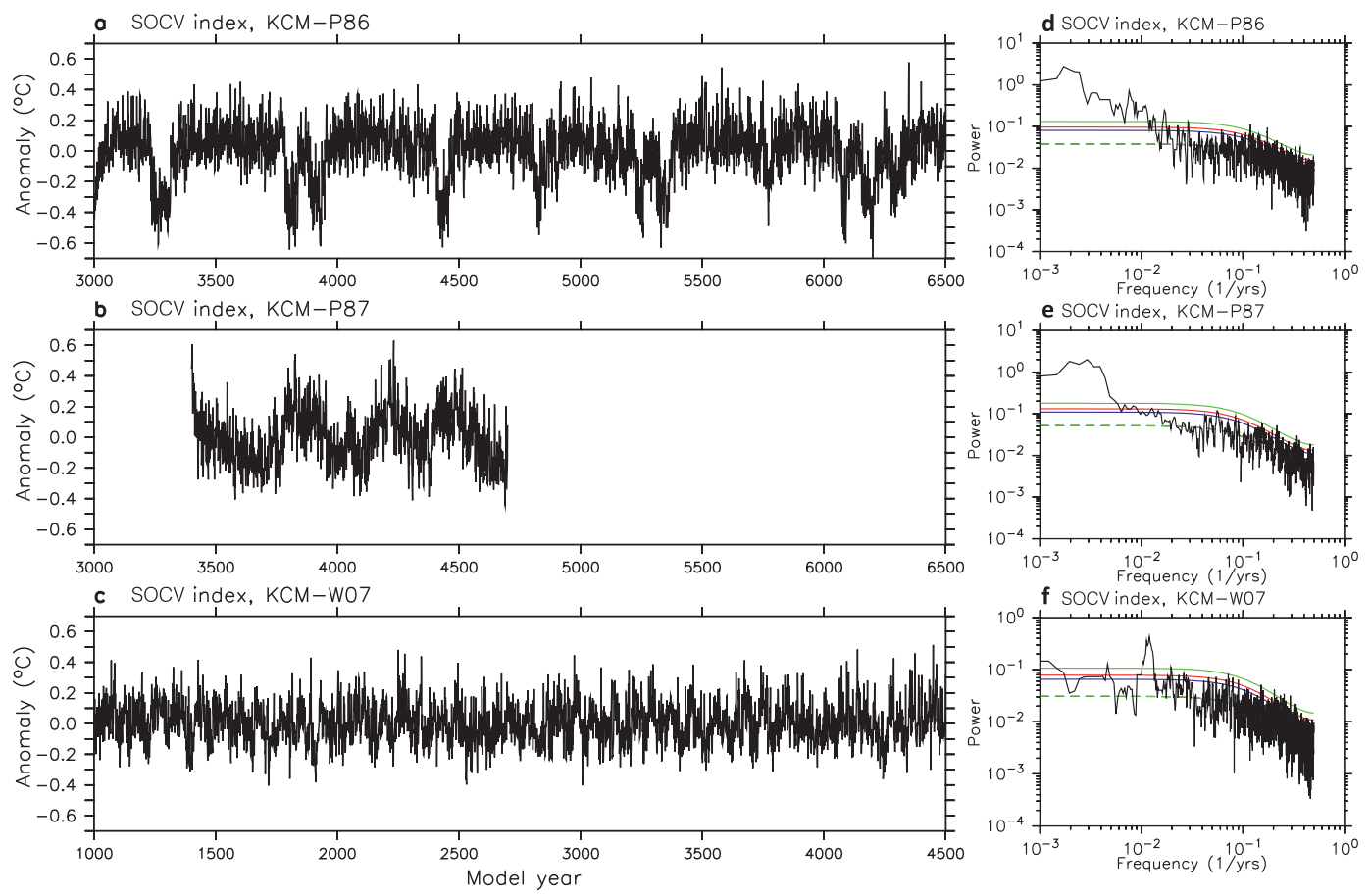

FIG. 11. The SOCV index $\left({ }^{\circ} \mathrm{C}\right)$ in three versions of the KCM. (a) The time series in the model version used in Park and Latif (2008), (b) the time series used in this study, and (c) the time series from a simulation in which the $\mathrm{T} 31\left(3.75^{\circ} \times\right.$ $\left.3.75^{\circ}\right)$ atmosphere model was replaced by a T42 $\left(2.8^{\circ} \times 2.8^{\circ}\right)$ version, whereas the horizontal ocean model resolution was kept at $2^{\circ}$. (d)-(f) The respective frequency spectra of the SOCV indices shown in (a)-(c) calculated by applying a multitaper method (see Ghil et al. 2002). Confidence levels are denoted by the solid green (99\%), red (95\%), and blue $(90 \%)$ lines and the median is denoted by the green dashed line.

Southern Ocean variability in the GFDL model with an SAT pattern similar to that in the KCM (A. Gnanadesikan 2013, personal communication).

The global three-dimensional ocean circulation and the mechanisms of its variability are not well known from observations (Rintoul et al. 2011). We have therefore to heavily rely on global climate models to understand the mechanisms of long-term climate variability, especially those operating in the Southern Ocean. The KCM, like other climate models, suffers from large biases. Processes important to Southern Ocean circulation variability such as mesoscale eddies (e.g., Böning et al. 2008) are not explicitly resolved and are instead parameterized (Gent and McWilliams 1990). Moreover, shelf convection (the main formation mechanism of the very dense Antarctic Bottom Water) is not present in the model. It is unclear at this stage of research how model bias affects the simulation of centennial variability. Comparison of the SOCV in the KCM with that simulated by other climate models will be helpful in this regard.

A strong sensitivity of the time scale of the SOCV to model formulation is noted. We show in Fig. 11 the SOCV indexes from three versions of the Kiel Climate Model together with the corresponding frequency spectra. Panels in the upper two rows of Fig. 11 show results from the two model versions of the KCM that are discussed in Martin et al. (2013). These two differ only in one single parameter in the sea ice parameterization, affecting the average thickness of the Antarctic sea ice cover. In Figs. 11c and 11f we show the SOCV index and frequency spectrum from a version of the KCM in which the T31 atmosphere model was replaced by a higher horizontal resolution T42 version, whereas the horizontal ocean model resolution was kept at $2^{\circ}$. Several ocean model parameters, however, are different in this version. Obviously, the periodicities in the three simulations are rather different, ranging from multidecadal to multicentennial and longer (Figs. 11d-f). The basic mechanism for the SOCV in the three KCM versions and the corresponding teleconnection patterns are found to be very similar [see Martin et al. (2013) for the mechanism in the two T31 coupled model versions shown in the upper two rows of Fig. 11].

Our model results suggest that the Southern Ocean plays an important role in the generation of internal centennial variability and that this variability has significant climate impacts, even outside the Southern Ocean sector. It remains unclear how much of the 
observed pattern of decadal changes in SST and other variables (and also the somewhat puzzling fact that sea ice extent has been increasing in the Antarctic) are due to a cessation of Weddell Sea deep convection. The differences between the model patterns and those observed during the recent decades are quite substantial. We need better proxies for long-term climate variability in the far Southern Ocean in order to better assess the model variability and verify the existence of enhanced centennial variability in the real world.

In conclusion, this study lends support to the assertion that internal SOCV is a key to understanding the twentieth-century climate and possibly also to predicting the climate of the twenty-first century. The results, however, are mostly based on only one global climate model. The SOCV affects global-average SAT in the model and may have also been one factor that retarded global warming during the recent years. If so, and given the long time scale of the SOCV in the model, the SOCV may continue to exert a damping on global warming during the next decades. Because in the model the SOCV is reflected in ocean heat content and sea surface height (not shown), the current ocean observing system, if expanded to monitor ocean heat content changes below $2000 \mathrm{~m}$, would enable prediction of the centennial mode's temporal evolution with adequately initialized climate models. This would enhance the skill of decadal climate projections. The predictability of this specific type of centennial variability is currently under investigation and will be the topic of a forthcoming paper.

Acknowledgments. The climate model integrations were performed at the Kiel University Computing Centre. NODC WOA98 data were provided by the NOAA/OAR/ESRL PSD, Boulder, Colorado, from their website (http://www.esrl.noaa.gov/psd/). This work was supported by the projects Nordatlantik and RACE of the German Ministry for Research and Technology (BMBF) and European Union's Seventh Framework Programme (FP7/2007-2013) under Grant Agreement 212643 [Thermohaline Overturning at Risk (THOR)].

\section{REFERENCES}

Arblaster, J. M., and G. A. Meehl, 2006: Contributions of external forcings to southern annular mode changes. J. Climate, 19, 2896-2095.

_ _ _ a and D. J. Karoly, 2011: Future climate change in the Southern Hemisphere: Competing effects of ozone and greenhouse gases. Geophys. Res. Lett., 38, L02701, doi:10.1029/ 2010GL045384.

Böning, C. W., A. Dispert, M. Visbeck, S. R. Rintoul, and F. U. Schwarzkopf, 2008: The response of the Antarctic Circumpolar Current to recent climate change. Nat. Geosci., 1, 864869.
Cane, M. M., A. C. Clement, A. Kaplan, Y. Kushnir, D. Pozdnyakov, R. Seager, S. E. Zebiak, and R. Murtugudde, 1997: Twentiethcentury sea surface temperature trends. Science, 275, 957960.

Carsey, F. D., 1980: Microwave observations of the Weddell Polynya. Mon. Wea. Rev., 108, 2032-2044.

Cavalieri, D. J., and C. L. Parkinson, 2008: Antarctic sea ice variability and trends, 1979-2006. J. Geophys. Res., 113, C07004, doi:10.1029/2007JC004564.

Comiso, J. C., and F. Nishio, 2008: Trends in the sea ice cover using enhanced and compatible AMSR-E, SSM/I, and SMMR data. J. Geophys. Res., 113, C02S07, doi:10.1029/2007JC004257.

Cook, E. R., B. M. Buckley, R. D. D'Arrigo, and M. J. Peterson, 2000: Warm-season temperatures since $1600 \mathrm{BC}$ reconstructed from Tasmanian tree rings and their relationship to large-scale sea surface temperature anomalies. Climate Dyn., 16, 79-91, doi:10.1007/s003820050006.

Delworth, T. L., and F. Zeng, 2012: Multicentennial variability of the Atlantic meridional overturning circulation and its climatic influence in a 4000 year simulation of the GFDL CM2.1 climate model. Geophys. Res. Lett., 39, L13702, doi:10.1029/ 2012GL052107.

Fahrbach, E., M. Hoppema, G. Rohardt, O. Boebel, O. Klatt, and A. Wisotzki, 2011: Warming of deep and abyssal water masses along the Greenwich meridian on decadal timescales: The Weddell Gyre as a heat buffer. Deep-Sea Res. II, 58, 25092523.

Galbraith, E. D., and Coauthors, 2011: Climate variability and radiocarbon in the $\mathrm{CM} 2 \mathrm{Mc}$ earth system model. J. Climate, 24, 4230-4254.

Gent, P. R., and J. C. McWilliams, 1990: Isopycnal mixing in ocean circulation models. J. Phys. Oceanogr., 20, 150-155.

Ghil, M., and Coauthors, 2002: Advanced spectral methods for climatic time series. Rev. Geophys., 40, 1003, doi:10.1029/ 2000RG000092.

Gordon, A. L., 1978: Deep Antarctic convection west of Maud Rise. J. Phys. Oceanogr., 8, 600-612.

1982: Weddell Deep Water variability. J. Mar. Res., 40, 199217.

- and J. C. Comiso, 1988: Polynyas in the Southern Ocean. Sci. Amer., 256, 90-97.

, M. Visbeck, and J. C. Cosimo, 2007: A possible link between the Weddell Polynya and the southern annular mode. J. Climate, 20, 2558-2571.

Graham, N. E., 1994: Decadal-scale climate variability in the tropical and North Pacific during the 1970s and 1980s: Observations and model results. Climate Dyn., 10,135-162.

Hegerl, G. C., and Coauthors, 2007: Understanding and attributing climate change. Climate Change 2007: The Physical Science Basis, S. Solomon et al., Eds., Cambridge University Press, 663-745.

Holland, D. M., 2001: Explaining the Weddell Polynya: A large ocean eddy shed at Maud Rise. Science, 292, 1697-1700.

Hurrell, J. W., 1995: Decadal trends in the North Atlantic Oscillation and relationships to regional temperature and precipitation. Science, 269, 676-679.

— annual cycle in the Southern Hemisphere. Tellus, 46A, 325338.

Kalnay, E., and Coauthors, 1996: The NCEP/NCAR 40-Year Reanalysis Project. Bull. Amer. Meteor. Soc., 77, 437-471.

Knight, J. R., R. J. Allan, C. K. Folland, M. Vellinga, and M. E. Mann, 2005: A signature of persistent natural thermohaline 
circulation cycles in observed climate. Geophys. Res. Lett., 32, L20708, doi:10.1029/2005GL024233.

Latif, M., and N. S. Keenlyside, 2011: A perspective on decadal climate variability and predictability. Deep-Sea Res. II, 58, 1880-1894, doi:10.1016/j.dsr2.2010.10.066.

Le Quesne, C., C. Acuña, J. A. Boninsegna, A. Rivera, and J. Barichivich, 2009: Long-term glacier variations in the central Andes of Argentina and Chile, inferred from historical records and tree-ring reconstructed precipitation. Palaeogeogr. Palaeoclimatol. Palaeoecol., 281, 334-344.

Levitus, S., and Coauthors, 1998: Introduction. Vol. 1, World Ocean Database 1998, NOAA Atlas NESDIS 18, 346 pp.

Mantua, N. J., S. R. Hare, Y. Zhang, J. M. Wallace, and R. C. Francis, 1997: A Pacific interdecadal climate oscillation with impacts on salmon production. Bull. Amer. Meteor. Soc., 78, 1069-1079.

Marshall, G. J., 2003: Trends in the southern annular mode from observations and reanalyses. J. Climate, 16, 4134-4143.

—, P. A. Stott, J. Turner, W. M. Connolley, J. C. King, and T. A. Lachlan-Cope, 2004: Causes of exceptional atmospheric circulation changes in the Southern Hemisphere. Geophys. Res. Lett., 31, L14205, doi:10.1029/2004GL019952.

Martin, T., W. Park, and M. Latif, 2013: Multi-centennial variability controlled by Southern Ocean convection in the Kiel Climate Model. Climate Dyn., 40, 2005-2022.

Martinson, D. G., P. D. Kilworth, and A. L. Gordon, 1981: A convective model for the Weddell Polynya. J. Phys. Oceanogr., 11, 466-488.

Meehl, G. A., A. Hu, and B. D. Santer, 2009: The mid-1970s climate shift in the Pacific and the relative roles of forced versus inherent decadal variability. J. Climate, 22, 780-792.

Mikolajewicz, U., and E. Maier-Reimer, 1990: Internal secular variability in an ocean general circulation model. Climate Dyn., 4, 145-156.

Moore, G. W. K., K. Alverson, and I. A. Renfrew, 2002: A reconstruction of the air-sea interaction associated with the Weddell Polynya. J. Phys. Oceanogr., 32, 1685-1698.

Park, W., and M. Latif, 2008: Multidecadal and multicentennial variability of the meridional overturning circulation. Geophys. Res. Lett., 35, L22703, doi:10.1029/2008GL035779.

— , and _ 2010: Pacific and Atlantic multidecadal variability in the Kiel Climate Model. Geophys. Res. Lett., 37, L24702, doi:10.1029/2010GL045560.

— response to idealized external forcing. Climate Dyn., 39, 17091726, doi:10.1007/s00382-011-1212-0.

— N. S. Keenlyside, M. Latif, A. Ströh, R. Redler, E. Roeckner, and G. Madec, 2009: Tropical Pacific climate and its response to global warming in the Kiel Climate Model. J. Climate, 22, 71-92.

Parkinson, C. L., 1983: On the development and cause of the Weddell Polynya in a sea ice simulation. J. Phys. Oceanogr., 13, 501-551.

Philander, S. G. H., 1990: El Niño, La Niña, and the Southern Oscillation. Academic Press, 289 pp.

Pierce, D. W., T. P. Barnett, and U. Mikolajewicz, 1995: Competing roles of heat and freshwater flux in forcing thermohaline oscillations. J. Phys. Oceanogr., 25, 2046-2064.

Power, S., T. Casey, C. Folland, A. Colman, and V. Mehta, 1999: Inter-decadal modulation of the impact of ENSO on Australia. Climate Dyn., 15, 319-324.
Purkey, S. G., and G. C. Johnson, 2010: Warming of global abyssal and deep Southern Ocean waters between the1990s and 2000s: Contributions to global heat and sea level rise budgets. J. Climate, 23, 6336-6351.

—, and — 2012: Global contraction of Antarctic Bottom Water between the 1980s and 2000s. J. Climate, 25, 5830-5844.

Randall, D. A., and Coauthors, 2007: Climate models and their evaluation. Climate Change 2007: The Physical Science Basis, S. Solomon et al., Eds., Cambridge University Press, 589-662.

Rintoul, S. R., 2007: Rapid freshening of Antarctic Bottom Water formed in the Indian and Pacific Oceans. Geophys. Res. Lett., 34, L06606, doi:10.1029/2006GL028550.

_ , and Coauthors, 2011: Deep circulation and meridional overturning: Recent progress and a strategy for sustained observations. Proceedings of OceanObs'09: Sustained Ocean Observations and Information for Society, Vol. 1, Venice, Italy, IOC/UNESCO, 21-25, doi:10.5270/OceanObs09.pp.32.

Robertson, R., M. Visbeck, A. L. Gordon, and E. Fahrbach, 2002: Long-term temperature trends in the deep waters of the Weddell Sea. Deep-Sea Res. II, 49, 4791-4806.

Santoso, A., M. H. England, and A. C. Hirst, 2006: Circumpolar deep water circulation and variability in a coupled climate model. J. Phys. Oceanogr., 36, 1523-1552.

Smith, T. M., R. W. Reynolds, T. C. Peterson, and J. Lawrimore, 2008: Improvements to NOAA's historical merged landocean surface temperature analysis (1880-2006). J. Climate, 21, 2283-2296.

Thompson, D. W. J., and S. Solomon, 2002: Interpretation of recent Southern Hemisphere climate change. Science, 296, 895 899.

— - - P. J. Kushner, M. H. England, K. M. Grise, and D. J. Karoly, 2011: Signatures of the Antarctic ozone hole in Southern Hemisphere surface climate change. Nat. Geosci., 4, 741-749, doi:10.1038/ngeo1296.

Torrence, C., and G. P. Compo, 1998: A practical guide to wavelet analysis. Bull. Amer. Meteor. Soc., 79, 61-78.

Trenberth, K. E., and J. W. Hurrell, 1994: Decadal atmosphereocean variations in the Pacific. Climate Dyn., 9, 303-319.

_ climate change. Climate Change 2007: The Physical Science Basis, S. Solomon et al., Eds., Cambridge University Press, 235-336.

Visbeck, M., 2009: A station-based southern annular mode index from 1884 to 2005. J. Climate, 22, 940-950.

Worby, A. P., C. A. Geiger, M. J. Paget, M. L. V. Woert, S. F. Ackley, and T. L. DeLiberty, 2008: Thickness distribution of Antarctic sea ice. J. Geophys. Res., 113, C05S92, doi:10.1029/ 2007JC004254.

Yin, F. L., and E. S. Sarachik, 1995: Interdecadal thermohaline oscillations in a sector ocean general circulation model: Advective and convective processes. J. Phys. Oceanogr., 25, 2465-2484.

Zunz, V., H. Goosse, and F. Massonnet, 2013: How does internal variability influence the ability of CMIP5 models to reproduce the recent trend in Southern Ocean sea ice extent? Cryosphere, 7, 451-468, doi:10.5194/tc-7-451-2013.

Zwally, H. J., and P. Gloersen, 1977: Passive microwave images of the polar regions and research applications. Polar Rec., 18, $431-450$. 